\title{
CHAPTER TEN
}

\section{Chinese Porcelain, the East India Company and British Cultural Identity, 1600-1800}

\section{Stacey Pierson}

Chinese ceramics have been part of domestic and public life in Britain since the sixteenth century. The first examples that arrived were often given metalwork mounts that transformed them into luxurious objects. ${ }^{1}$ Subsequently, imported ceramics were used without adornment in daily life, particularly at table, becoming a familiar domestic object. As a result of their incorporation into British life in the seventeenth and eighteenth centuries, these ceramics have been extensively studied and much is known about the consumption of Chinese ceramics in Britain, particularly in domestic life as well as in specific locations such as public inns or at court. The sources for information about the consumption of Chinese ceramics in Britain range widely, from archaeology, to diaries and literature, household inventories, and cultural histories of dining and drinking. ${ }^{2}$ Information about the stylistic features of the porcelains, often classified as 'export wares,' is also widely published, generally in survey histories of Chinese export porcelain, as well as more specialist texts on aspects of Chinese export wares such as 'armorial porcelain'. ${ }^{3}$ The mechanics of this export trade, and the movement of Chinese porcelain in general, are explored in histories of the global commodity trade, especially from Asia. ${ }^{4}$ 
An important mechanism for the movement of Chinese porcelain was the merchant trading companies that were established in Britain and Europe after 1600. The English company, known as the East India Company (EIC), was responsible for the movement of hundreds of thousands of Chinese porcelains, as well as their distribution in Britain and its overseas colonies. The literature on the EIC is vast but some works are particularly focused on the trade in objects and commodities and the lifestyles of company employees. ${ }^{5}$ What none of these texts address, however, is what these Chinese porcelains represented for British consumers. The general assumption is that they were simply exotica, and a mirror for attitudes about China. ${ }^{6}$ However, as this chapter will demonstrate, they were also a representation of Britain and British people. Through consumption and design, a change in identity was imposed on the porcelains used in Britain and by British consumers in other locations. An account of the global reception and consumption of Chinese porcelain of the Ming dynasty (1368-1644) and its impact on the objects was published in my book From Object to Concept, but the seventeenth and eighteenth centuries have only been lightly touched upon from this perspective. ${ }^{7}$ As a case study for the role of objects in shaping and affirming cultural and national identities, Chinese porcelain and the EIC would seem to be ideal in light of the documented use of Chinese porcelain at most EIC outposts around the world, and its commissioning by identifiable consumers both directly and indirectly associated with the Company.

\section{Private commissions and armorial wares}

Some Chinese porcelain was available in Britain before the establishment of the EIC but certain types were not, particularly privately-commissioned wares, such as what are known as 'armorial wares', decorated with family crests, and bowls for the drinking of punch from India. The popularity of these types, which were associated with commodities from Asia, 
suggests that the EIC's imports and its fulfilling of private commissions had a notable impact on British daily-life activities of the late seventeenth to nineteenth centuries. The imported products provided a physical link to the provider of Asian goods, particularly tea and porcelain. The private trade, accessory to official Company trade, is quite important in this because it was through this secondary trade mechanism that special commissions were carried out. Recent research in the records of the Dutch East India Company (VOC) suggests that the private trade was more substantial by volume than Company trade, but, while significant, that was not the case for the EIC. ${ }^{8}$ Nevertheless, EIC private trade played a central role in specially-commissioned objects. It is these works that are most often dated, and tell us the most about how they were used, and what they represented to their consumers. Initially, the EIC private trade was tolerated, rather than actively encouraged. According to Anthony Farrington, who has written extensively about the EIC, later in the seventeenth century '...the English Company began to concede regulated opportunities for private enterprise. Rules drawn up in 1674 allowed its servants...to trade from port to port within Asia in all but a few commodities which were entirely reserved for the Company. ... Once the regular trade at Canton was established the Company came to concentrate on three principal commodities - tea, silk textiles, and inexpensive porcelain. All the 'fancy' goods and special orders, for example for armorial porcelain or large decorative pieces, were left to the private trade of their servants and ships' officers' ${ }^{9}$

If we turn now to a few examples of Chinese porcelains produced for and used by individual members of the EIC, we can get a sense of how they were incorporated into and shaped the material and social worlds of mercantile Britain in the seventeenth and eighteenth centuries. As noted above, one major, well-known category of what might be called 'British Chinese porcelain’ was armorial ware (porcelains decorated with family or company crests). 
(for an example, see fig. 10.1) The first English armorial porcelains were commissioned in the late seventeenth century, the earliest known example being a planter for an EIC shipbuilder, Henry Johnson of Blackwall in Middlesex. ${ }^{10}$ In simple terms, through their decoration, armorial objects declare both the personal identity of the consumer and ownership of the vessels (and they were almost always vessels instead of figurines). With the armorial decoration, the vessels are no longer anonymous. Making such vessels from porcelain in China was much easier (and cheaper) than doing so in other materials such as silver, which would have been one of the few alternatives available in Britain at that time as porcelain was not yet manufactured as a product in England before the 1750s. The availability of porcelain armorial vessels also coincided with (or perhaps stimulated) a fashion in Northern Europe for large dinner services with matching sets of vessels, which began to appear around 1700, a fashion made possible as a result of EIC trade in Chinese goods. ${ }^{11}$ For example, dinner services represented a certain approach to dining which moved beyond central serving vessels and few courses to multiple courses and individual servings, a practice which first emerged in the mid-seventeenth century but was very expensive before the availability of porcelain dishes in quantity. These armorial dinner services (or pieces from them) can tell us much about dining habits, therefore, but also about who was dining in this way and where. The earliest surviving porcelain dining service was made for Governor (Thomas) Pitt of Madras (1653-1726) in 1705, who went to India with the EIC. ${ }^{12}$ This service is decorated with underglaze blue and overglaze enamel designs in a style known as 'Chinese Imari', after the Japanese ware which was copied in China in the seventeenth and eighteenth centuries.(see fig. 10.1) The figurative decoration on these pieces is primarily Chinese but with the addition of a foreign crest, demonstrating a desire for the 'Chineseness' of the vessels to be retained. This visual hybridity provided information about the consumer and his access to trade goods from 
afar, as well as his desire to be represented as a member of the British elite who would be in possession of a family crest.

\section{[Insert Figure 10.1 near here]}

\section{Dining and drinking}

From the early eighteenth century, a wider consumer group for such porcelains developed, interestingly moving from EIC members and investors (merchants) to aristocratic families, then other companies and businesses, and finally even to women as individual commissioners. This pattern of consumption would appear to contradict the usual assumption that taste passed from the top down and is reinforced visually by stylistic developments in this ware. For example, from the 1720s, the decorative style of British Chinese porcelain began to change, minimizing Chinese designs and patterns, so that its Asian origins were all but eliminated. The new domestic-style designs prominently reflected the tastes and lifestyles of the newer consumers, from multiple levels of society. A typical example is the coffee pot in figure 10.2 which takes its form from English silver and dates from c. 1730-40. It features as its main decoration the arms of the Clifford family of Chudleigh, members of the aristocracy whose ancestral home is Ugbrooke in Devon, England. ${ }^{13}$ Not only does this piece prominently represent that particular elite consumer group but it also reveals the continuation of fashionable drinking practices from the previous century (coffee) and the origins of the forms for such vessels, which were not Chinese. In the analysis of these wares, the absence of Chinese designs or forms in Chinese porcelain is something that is often seen as surprising from both an art historical and a consumer perspective, as the objects were of Chinese manufacture and seemingly desirable by association. But the absence is not unusual if it is 
considered from a socio-cultural perspective. The key is that once porcelain from China became readily available in Britain after the 1720s, and therefore not exclusive, it no longer needed to be visually Chinese, declaring its exotic origins. Instead, by a certain date, Chinese porcelain merely provided the medium for the making of a visually British object which therefore is only materially Chinese. It also was not limited in design by its producers. Any design could be made in or on Chinese porcelain and therefore consumers had a choice. When given this choice, they did not, for the most part, choose Chinese designs.

\section{[Insert Figure 10.2 near here]}

In another example, also representing an elite pastime, yet one which was reserved primarily for the upper classes (unlike coffee drinking), fox hunting is illustrated. Such scenes were popular in visual arts at this time, and therefore it is not surprising that they should also appear on armorial porcelains (see color figure 26). Designs for these scenes could easily be sent to China where they were readily copied. The ability to copy any design or form in porcelain is an indication of the role that advance manufacturing technology played in this type of cross-cultural material translation. On this vessel, there is a narrative scene as well as an armorial which are signifiers of identity. The hunting scene is further derived from a print of a painting by James Seymour (?1702-52), whose work was admired by the gentry. ${ }^{14}$ The image on the porcelain dish therefore has been translated through several media. There are layers of meaning embedded in this dish centred around the armorial which declares that this piece was made for the May family of London and Sussex who can be seen to embody the aristocratic lifestyle through their consumption of individualized Chinese porcelains.

[Reference to color figure 26 here] 
Interestingly, women of the gentry sometimes had their own armorial porcelain, indicating that they too were commissioners, not just passive consumers as is commonly assumed. The sauce tureen in figure 10.3 was made for the Countess of Macclesfield (Dorothy Nesbitt, d. 1779), who was a widow as can be seen from the shield which is a lozenge or diamond shape. The vessel itself was copied from an English creamware version which in turn took its form from silver. ${ }^{15}$ Visually there is nothing remotely Chinese about this tureen. Even materially, it is disguised to look like another type of ceramic. While it may have been ordered as a replacement piece, this imitation is significant on several levels. Firstly it is further evidence that from the 1720s, Chinese porcelain was not always associated visually with China in Britain. In fact, its origins or place of manufacture were deliberately obscured in this case. Its identity as an imitation was part of its appeal and represents a form of intellectualized taste. Secondly, this was facilitated by the fact that one of the attractions of ordering porcelain from China, apart from cost, was the advanced technology that could be utilized to make almost anything a customer desired, including an imitation 'British’ ceramic.

\section{[Insert Figure 10.3 near here]}

This tureen is part of a dinner service, but it should be noted that such services were not only used by wealthy individuals or families but also by companies, including the EIC. As an example in the Victoria and Albert Museum demonstrates, 'grand services ... decorated with arms taken from the bookplate of the Company, were used by senior staff in India.' ${ }^{16}$ The pieces from the service shown in figure 10.4 '...came from Fort St George, Madras (now Chennai), the centre of British trade in Asia, and may have been ordered to celebrate the Company's centenary. Many EIC governors took parts of services back with them at the end of their tenure in office. .... ${ }^{17}$ They were therefore portable personal and company goods for British consumers overseas that happened to be made in China and the 
service was also commemorative, celebrating a key event in company history. Another slightly earlier service for the EIC in the collection at Winterthur was clearly a more generic one in that it was made in a standard form in rather plain blue and white, ${ }^{18}$ and was either for use on the company ships or for one of its trading settlements in the East, thus preserving the British way of life away from Britain using Chinese goods. This set was nonetheless exclusive, branded as it was with the company crest. The company was therefore following the same taste and consumption patterns as individuals, declaring and presenting its identity with goods ordered through its commercial access and consuming these goods in its many locations.

\section{[Insert Figure 10.4 near here]}

\section{Tea and porcelain}

Dining habits and armorial wares are only one area of Chinese porcelain consumption facilitated by the EIC. Porcelain was also found to be essential for certain drinking practices, as we have seen with the earlier example of coffee. Another stimulant drunk from porcelain vessels, tea, was also distributed by the EIC. Unlike coffee it was a Chinese product and its trade and consumption was arguably one of the most important social, material and economic developments of the later seventeenth to eighteenth centuries. The history of tea consumption in Britain is well known, but what is less well understood is the relationship between tea and porcelain. As a medium, porcelain was an important facilitator for both the simple drinking of tea but also the presentation, shipping and storage of it, thus contributing to both trade in the commodity and the social practice of tea drinking which initially was heavily gender-andclass driven. Until the mid-eighteenth century tea drinking was mainly reserved for the upper 
classes and controlled by the women of the family. Eventually, with changes in taxation, tea drinking was also to become part of everyday life at lower levels of British society.

Tea became a valuable and profitable commodity from the late seventeenth century onward and large quantities of tea were only available from China at that time. Most bulk tea was transported by sea and porcelain was a useful accessory product that could both weight the ships as additional ballast and line the bottom holds to protect the tea above from damp and odour contamination. ${ }^{19}$ In this context, tea was therefore the profitable commodity and porcelain was the additional (but desirable) product which facilitated the tea trade. Its usefulness was further enhanced by its abundance. No other manufactured product was both readily available in the tea producing area, mass-produced and therefore relatively cheap, durable, and then saleable in Europe after serving its shipping function. ${ }^{20}$

As tea was predominantly a Chinese product (until the nineteenth century), vessels made from Chinese porcelain would have seemed a natural accompaniment to the drink. Once again, the EIC made accessible and more widely available the material considered essential for the practice of tea drinking, as well as the tea itself. The porcelain tea wares transported, consumed and indeed collected by members of the EIC and its employees reveal much about the material worlds of Britain - both their practical sides as well as their visual and cultural ones. Many tea porcelains associated with the EIC survive, and like the general category of 'armorial porcelains', they often reflect similar trends in design, identity expression and social practices, especially those with family or company crests. At first, tea wares were individual items but these later developed into more complete services, as the practice of tea drinking became more elaborate and thus materially more complex. A complete tea service consisted of a teapot, milk jug, sugar bowl, slop bowl, tea caddy, spoon tray, cups and saucers (usually 12). ${ }^{21}$ One surviving tea caddy features the armorial of 
Benjamin Torin who served as a supercargo and EIC council member in Canton in the mideighteenth century (see color figure 27). Its design cleverly adopts the Chinese convention for representing scholars examing scrolls as a frame for the armorial, which appears on the scroll alongside the left figure poised with a paintbrush, visually and symbolically inserting the owner of the vessel into the scene. This is analogous to similar pictorial conceits in Chinese painting, such as the famous portrait of the Qianlong emperor shown viewing objects with his own portrait behind him. ${ }^{22}$

\section{[Insert color figure 27 near here]}

A teapot of a similar date features the arms of a captain in the Royal Navy (Richard Latham), and like the caddy, it still features very Chinese-style designs, in this case a traditional watery landscape scene with monumental rocks in the background, of a type featured on many domestic and export porcelains from the late Ming period onward. ${ }^{23}$ It is painted in blue and white but with a polychrome armorial crest placed centrally on the shoulder of the pot, an incongruous western design element inserted into a Chinese vista. As we have seen with armorial dishes, this approach to design, retaining a Chinese style by utilizing stock Chinese decorative patterns, would change shortly after the first quarter of the eighteenth century to reflect new fashions outside of China, including Neoclassical styles and the forms of contemporary silver. For example, the teapot in figure 10.5 belonged to a member of the gentry and in design terms, could easily be English or European. There are no Chinese elements and the most prominent motif is the coat of arms.

\section{[Insert Figure 10.5 near here]}

Other members of the British elite also commissioned tea wares, including the painter Joshua Reynolds (1723-92) who even designed his own monogram for his service which 
clearly post-dates his knighthood. ${ }^{24}$ Decorated in a style popular in the American market, with a so-called 'Fitzhugh border' and rose palette, the centrally-placed monogram imitates the stylistic conventions for armorials, thus demonstrating the visual power of such imagery for British cultural identity. Certainly it can be argued that the popularization of armorials was facilitated by Chinese porcelain which enabled them to be readily reproduced and importantly displayed in quantity.

\section{Popular visual culture and politics}

British Chinese porcelains could also feature more topographical designs and reveal not only more widespread consumption of personalized sets of porcelain vessels but also what such sets might be used for beyond their basic function as vessels. One very interesting example was made for and presented as a gift for a cobbler who had looked after a gentleman who had escaped from a sinking East Indiaman ship off the coast of Rye in East Sussex, England. (see color figure 28 and fig. 10.6). The design features the initials of the cobbler, R P or Richard Philcox, in the style of an armorial, thus further demonstrating that this was considered a standard and desirable visual style for such wares. On the other side of the pot there is also a little vignette of a cobbler at work, with a common expression of the time, 'I must work for leather is dear', painted above. Scenes of working life were quite fashionable in later eighteenth - century prints and some trade cards, which might have provided a source for the design. ${ }^{25}$ But working life associated with the China trade, particularly tea, was also depicted on some of these porcelains, such as the dish in the next example. (see color figure 29) Like the previous pieces, this dish also features a kind of pseudo-armorial, here as a frame for the design, but the imagery is not of an English craftsman at work. Instead it depicts an English inspector at work above a Chinese tea packer - an unusual scene on porcelain but one seen in 
paintings of the time. The motto, 'labor itself is a pleasure' is seen in armorials of three families and the border decoration of the dish is borrowed from Viennese porcelain of the first half of the eighteenth century. ${ }^{26}$ Thus this dish combines imagery from multiple sources but more importantly, it also features a stylised visual reference to the work of the tea merchant in the form of an armorial - a new approach to design which too was facilitated or inspired by the activities of the EIC. It literally brought these activities into the home, on the dinner service - referencing tea and trade in another context.

\section{[Insert Figure 10.6 near here]}

\section{[References to Color Figure 28 and Color Figure 29 here]}

A final type of British Chinese porcelain which we need to consider in a study of Chinese porcelain and identity representation in Britain, is also one associated with a drink brought to England by the EIC. This drink was punch, which was first drunk fairly widely from the 1680s. Its '... name derived from Hindi, and was a drink brought back from India to England by sailors and employees of the EIC in the early $17^{\text {th }}$ century. The drink was mixture of wide variety of elements, including spirits and fruit juice, with early ones based on wine or brandy, and then rum after the mid- $17^{\text {th }}$ century, as well as Jamaican sugar cane' ${ }^{27}$ Like tea, punch required special vessels but unlike tea, these were large and communal. When porcelain became more readily available, porcelain punch bowls became fashionable, especially from the 1740s onward. This medium also enabled (or partly inspired) the use of the wide expanse of space available on large punch bowls for a different type of visual imagery than on tea vessels - imagery related to social and political commentary. Some punch bowls featured simple armorials or scenes of gentry life, such as fox hunting, which we saw earlier, but many others were used to make a statement or to commemorate an event, possibly because the drinking of punch was a very public and social activity. 
One example of a punch bowl with overtly nationalist decoration is in the collection at the Winterthur Museum. This bowl features the arms of the Anti-Gallican Society which was founded to “”...discourage the Introduction of French modes and the Importation of French commodities", ${ }^{28}$ The most famous punch bowls with anti-French, and therefore pro-British decoration, are those featuring designs copied from Hogarth (1697-1764) prints such as one with a scene from 'The Gate of Calais'. ${ }^{29}$ (fig. 10.7) This particular version has replaced the arms of England that originally appeared above the gate in the print with those of Sir Thomas Rumboldt, from an EIC family, who served with Robert Clive at the Battle of Plassey and later as Governor of Madras. If this bowl were part of a larger service used by Rumboldt while overseas, it would have been a good example of how Chinese porcelain enabled both the representation of British identity and culture outside Britain as well as the movement of British visual and material culture around the trading world of Britain. Through this bowl and its counterparts, Hogarth's designs were disseminated through another medium. Rumboldt's ability to participate in and crucially appreciate both trade and domestic art production is represented visually in this porcelain punch bowl, wherever he was located.

\section{[Insert Figure 10.7 near here]}

\section{From China but not in China}

The final object examined in this chapter is another punch bowl that is political in nature but relating visually to the commercial aspects of the British Empire. It demonstrates visually that 1757 was an important year for the EIC, not just in India (the Battle of Plassey), but also in China, for it was in this year that the Chinese government finally agreed to make Canton the only port open for official trade with Europeans and the British. (see Color Figure 30) The 
warehouses (or 'factories') for six nations, including Britain, are depicted on this bowl as they were built along the Pearl River. The design translates architectural renderings onto a curved surface and represents the acquisition of a small amount of power over the Chinese by Europeans and the British. However, the location depicted, the port at Canton, is where British traders lived only during the season (not being allowed into Canton itself). Here they nonetheless maintained a British way of life, with 'British' material goods and practices because they were not permitted to live in China. They were physically present in China, the source of some of the primary material goods and provisions consumed in eighteenth- to nineteenth- century Britain, but they were not living in China so their own way of life came with them. Through their material goods, their national and personal identities came too. This form of social and object movement demonstrates one of the many ways in which Chinese products were incorporated into and shaped the material worlds of Britain, wherever they were located.

\section{[Reference to Color Figure 30 here]}

\section{Conclusion}

That Chinese porcelain could be British and a representation of British national and cultural identity, is clearly a function of its role in trade, particularly trade in Chinese commodities. We think very little today of bringing our material selves with us when we travel or move abroad, and this is what members of the EIC did when they moved around the world. They also utilized these channels to bring goods home and present to the world their significance. What is seemingly unusual is the use of a foreign raw material, porcelain, and foreign producers, to make the goods that represented Britain and British life. It is less unusual 
however when viewed from the perspective of the global nature of daily life in Britain after the advent of the EIC and the empire. Britons drank tea and wore silks from China, they ate off porcelain dishes from China and flavoured their food with spices from South and Southeast Asia and sugar from the West Indies. A study of the relationship between the EIC and porcelain in the seventeenth and eighteenth centuries provides evidence for this, but an examination of the porcelains themselves also demonstrates the impact of consumption on objects and the role that objects play in identity formation and representation. The impact on the objects is often visible, in terms of signs of wear or even decoration, but it is more often than not invisible and conceptual. These foreign-made objects help consumers to define themselves and represent their actual or desired position in society. Through this mechanism, porcelain from China could become a British product, but one made in China, much like many consumer goods today.

\footnotetext{
${ }^{1}$ See Pierson, Collectors, Collections; Pierson, 'Movement of Chinese Ceramics’.

${ }^{2}$ For evidence regarding the consumption of Chinese porcelain in England, for sources in archaeology, see Bracken, ' "Chyna” in England'; Allan, Medieval and Post-Medieval; for diaries and literature, see Bray, Diary of John Evelyn; Defoe, A Tour 'Thro; Lamb, 'Old China'; for household inventories see Japan Society, The Burghley Porcelains; Macgregor, The Late King's Goods; and for cultural histories of dining and drinking see Glanville and Young, Elegant Eating; Day, Eat, Drink and Be Merry.

${ }^{3}$ For survey histories of Chinese export porcelain see Sargent, Treasures of Chinese Export; Kerr and Mengoni, Chinese Export Ceramics; and Fuchs, Made in China. For more specialist texts on aspects of Chinese export wares, such as ‘armorial porcelain', see Howard, Chinese Armorial Porcelain.

${ }^{4}$ See Berg, ‘Asian Luxuries’; Batchelor, ‘On the Movement of Porcelains’; Pomeranz, The Great Divergence.

${ }^{5}$ See for example Farrington, Trading Places; and Erikson, Between Monopoly and Free Trade.

${ }^{6}$ Chang, Britain’s Chinese Eye.

${ }^{7}$ I touched on these issues in Pierson, 'Movement of Chinese Ceramics'.

${ }^{8}$ See van Campen and Eliens, eds., Chinese and Japanese Porcelain; Erikson, Between Monopoly and Free Trade.

${ }^{9}$ Farrington, Trading Places, p. 77, p. 87.

${ }^{10}$ Howard, A Tale of Three Cities, p. 95.
} 
${ }^{11}$ Pierson, Collectors, Collections.

${ }^{12}$ Howard, Chinese Armorial Porcelain, p. 176, B1.

${ }^{13}$ Lu, Mengoni, Passion for Porcelain.

${ }^{14}$ Fuchs, Made in China, p. 75.

${ }^{15}$ Fuchs, Made in China, p. 97.

${ }^{16}$ Kerr and Mengoni, Chinese Export Ceramics, pp. 9-10.

${ }^{17}$ Kerr and Mengoni, Chinese Export Ceramics, pp. 9-10.

${ }^{18}$ Fuchs, Made in China, p. 84.

${ }^{19}$ Jacobs, Merchant in Asia, p. 189.

${ }^{20}$ Pierson, 'Production, Distribution, and Aesthetics’.

${ }^{21}$ Fuchs, Made in China, p. 107.

${ }^{22}$ See One, or Two? in the collection of the Palace Museum, Beijing.

${ }^{23}$ The teapot has collection number Winterthur L03.2775.76a,b. It is published in Fuchs, Made in China, p. 117.

${ }^{24}$ Reynolds' service is housed in the Peabody Essex Museum, with collection number PEM E83352.AB.

${ }^{25}$ Murphy, Studies in Ephemera.

${ }^{26}$ Sargent, Treasures of Chinese Export.

${ }^{27}$ Kerr and Mengoni, Chinese Export Ceramics, p. 36.

${ }^{28}$ Fuchs, Made in China, p. 135.

${ }^{29}$ The prints were based on the painting of the same name that was produced by Hogarth in 1748 . It is now in the Tate Gallery in London, collection number N01464.

Bibliography

Allan, J. P. Medieval and Post Medieval Finds from Exeter 1971-1980. Exeter: University of Exeter Press, 1984.

Batchelor, R. 'On the Movement of Porcelains: Rethinking the Birth of Consumer Society as Interactions of Exchange Networks, 1600-1750'. In Consuming Cultures, Global Perspectives: Historical Trajectories, Transnational Exchanges, eds. John Brewer and Frank Trentmann (Oxford: Berg, 2006), pp. 95-121.

Berg, M., 'Asian Luxuries and the making of the European Consumer Revolution'. In Luxury in the Eighteenth Century: Debates, Desires and Delectable Goods, eds. Maxine Berg and Elizabeth Eger (Basingstoke: Palgrave Macmillan, 2003), pp. 228-244. 
Bracken, S. ““Chyna” in England Before 1614’, Oriental Art XLVII, no. 2 (2001): pp. 8-10.

Bray, William ed. The Diary of John Evelyn, Esq., F.R.S., from 1641 to 1705-6. With Memoir. 2 vols. London: J.M. Dent, 1818.

Campen, Jan van and Titus Eliens, eds. Chinese and Japanese Porcelain for the Dutch Golden Age. Amsterdam: Waanders, 2014.

Chang, Hope. Britain's Chinese Eye. Literature, Empire and Aesthetics in Nineteenth-century Britain. Stanford: Stanford University Press, 2010.

Day, Ivan ed. Eat Drink and Be Merry: the British at Table 1600-2000. London: Philip Wilson, 2000.

Defoe, Daniel. A tour thro' the whole island of Great Britain, 1724-27. G.D.H. Cole and D.C. Browning, eds. London: J.M. Dent, 1962.

Erikson, Emily. Between Monopoly and Free Trade: the English East India Company, 16001757. New Jersey: Princeton University Press, 2014.

Farrington, Anthony. Trading Places: the East India Company and Asia, 1600-1834. London: British Library, 2002.

Fuchs, R. Made in China. Delaware: Winterthur Museum, 2005.

Glanville, Philippa and Hilary Young, eds. Elegant Eating: Four Hundred Years of Dining in Style. London: V\&A Publications, 2002.

Howard, D. S. Chinese Armorial Porcelain. London: Faber, 1974.

Howard, D. S. A Tale of Three Cities: Canton, Shanghai and Hong Kong. Three Centuries of Sino-British Trade in the Decorative Arts. London: Sothebys, c. 1997.

Jacobs, E. M. Merchant in Asia: the Trade of the Dutch East India Company during the Eighteenth Century. Leiden: CNWS, 2006.

Japan Society, New York. The Burghley Porcelains, an Exhibition from the Burghley House Collection and Based on the 1688 Inventory and 1690 Devonshire Schedule. New York: Japan Society, 1980.

Kerr, Rose and Luisa Mengoni. Chinese Export Ceramics. London: V\&A Publications, 2011. Lamb. Charles. 'Old China'. In E.V. Lucas. ed. The Works of Charles and Mary Lamb, 7 vols. London: Methuen, 1903. Vol. 2, pp. 169-171.

Lu, Zhangshen, Luisa Megoni et al. Passion for Porcelain. Masterpieces of Ceramics from the British Museum and the Victoria and Albert Museum. Beijing: Zhonghua shu ju, 2012.

Macgregor, Arthur, ed. The Late King's Goods: Collections, Possessions and Patronage of Charles I in the Light of the Commonwealth Sale Inventories. Oxford: Oxford University Press, 1989. 
Murphy, K., et al, eds. Studies in Ephemera - Text and Image in $18^{\text {th }}$ century Prints. Plymouth: Roman \& Littlefield, 2013.

Pierson, Stacey. Collectors, Collections and Museum: the Field of Chinese Ceramics in Britain, 1560-1960. Bern: Peter Lang, 2007.

Pierson, Stacey. 'The Movement of Chinese Ceramics: Appropriation in Global History'. Journal of World History 23, no. 1 (Mar. 2012): pp. 9-39.

Pierson, Stacey. From Object to Concept: Global Consumption and the Transformation of Ming Porcelain. Hong Kong: Hong Kong University Press, 2013.

Pierson, Stacey. 'Production, Distribution and Aesthetics. Abundance and Chinese Porcelain from Jingdezhen 1300-1850'. In Monica Smith, ed., Abundance: and Archaeological Analysis of Plenitude. Boulder: University Press of Colorado, forthcoming (2017).

Pomeranz, Kenneth. The Great Divergence: China, Europe, and the Making of the Modern World. New Jersey: Princeton University Press, 2000.

Sargent, William 2012. Treasures of Chinese Export Ceramics. Yale University Press. 